\title{
Porous asphalt pavement for traffic noise reduction and pavement dewatering - the pollution problem
}

\author{
Lesław Bichajło ${ }^{1, *}$, Krzysztof Kołodziej ${ }^{1}$ \\ ${ }^{1}$ Rzeszów University of Technology, Faculty of Civil and Environmental Engineering and \\ Architecture, Poland
}

\begin{abstract}
The paper characterizes the porous asphalt mixture used in pavement construction. This kind of pavement can reduce traffic noise and reduce the slipperiness of the road pavement. The effectiveness of the porous asphalt depends on many design and technological aspects, but especially on the air-void clearance in the pavement layer. The paper includes the results of water permeability research based on laboratory tests of specimens from actual road pavement. The research shows the differences between the contamination of the road pavement sections located inside and outside the city. The paper includes recommendations for using porous asphalt based on experiences under Polish conditions.
\end{abstract}

\section{The porous asphalt characteristics}

Porous asphalt was developed in 1967 in Great Britain in order to ensure the rapid drainage of the surface during precipitation and elimination of the phenomenon of "aquaplaning". In typical mineral-asphalt mixtures, the air-void content is $3-8 \%$. In porous asphalt, the content of air-voids is in the range of $18-24 \%$ (wearing layer) and $24-28 \%$ (bonding layer) [1]. In the mixture of porous asphalt, small fractions (sand and filler aggregate) are omitted. As a result, a chamber system is formed inside the mass of the asphalt, in which acoustic wave loses its energy, which leads to a reduction of traffic noise.

At the same time, these surfaces are used as drainage surfaces, due to the possibility of absorption and drainage of the water from the surface of the pavement to drainage devices (prevention of aquaplaning). These indisputable advantages of surfaces made of porous asphalt are the reasons for their use in locations where the reduction of the road noise from car wheels is required, as well as in places with impaired surface drainage of rainwater (small longitudinal and transverse inclinations, concave vertical arches). Between the porous layers and the sealing layer of traditional mixes, it is recommended performing the sealing by spraying the traditional layer with an emulsion of asphalt or modified asphalt and sprinkling with fine aggregate [2].

It is estimated that the durability of a pavement with porous asphalt is about 8 to 10 years, while classic asphalt concrete has an estimated life expectancy of 10 to 12 years [3].

\footnotetext{
* Corresponding author: 1bichajlo@prz.edu.pl
} 
The experience of such countries as Germany, Japan or the Netherlands allows stating that due to the proper approach to the design of porous asphalt surfaces and their subsequent proper maintenance, it is possible to ensure adequate durability as well as durability of such a structure $[4,5]$.

\section{The level of noise reduction, if porous asphalt is used for the pavement}

In studies [2], it was found that at a speed of $80 \mathrm{~km} / \mathrm{h}$, the noise from a passenger car on asphalt concrete and SMA pavements was comparable (75.2-75.5 dBA), while on porous asphalt it was $70.1 \mathrm{~dB}$, which is about $5 \mathrm{~dB}$ less.

Two-layer porous surfaces allow reducing the noise associated with rolling wheels by up to $8 \mathrm{~dB}$ compared to medium-grained asphalt concrete [5]. The physical model of such a surface assumes the partial absorption and partial reflection of the acoustic wave from vehicle wheels [6]. The results of investigations of porous surfaces [7] indicate a higher value of acoustic noise absorption of two-layer surfaces. For the one-layer porous asphalt surface, it was found that immediately after the exchange, the noise suppression efficiency expressed by the effective sound power level increases with increasing vehicle speed. For a velocity of $20 \mathrm{~km} / \mathrm{h}$, the noise reduction was about $4.5 \mathrm{~dB}$, for $40 \mathrm{~km} / \mathrm{h}$ by about $6 \mathrm{~dB}$, and for $60 \mathrm{~km} / \mathrm{h}$ by about $7 \mathrm{~dB}$. After 3 years of operation, this efficiency was up to $2 \mathrm{~dB}$ in the whole speed range. For the two-layer surface, immediately after the exchange, the effectiveness was 10, 8 and $6 \mathrm{~dB}$ respectively, and after 2 years it decreased and was about 1-2 dB lower than for traditional asphalt concrete. The pollutants accumulated in the pores of the surface were given as the main reason for reducing the effectiveness of damping

Pavement surfaces of porous asphalt should not be used at specific places where deformation or a change of pavement structure may occur resulting in the reduction of pores or the interruption and clogging of connecting tubules; these pavements should not be made on longitudinal slopes greater than $10 \%$, on horizontal curves in the plan with a radius less than $75 \mathrm{~m}$ [8], in places exposed to constant dirt (the possibility of driving agricultural and construction machines, a neighbourhood of fields (the wind blows small particles of soil clogging the pores) and industrial plants emitting dusts and on roads with the speed limited to $55 \mathrm{~km} / \mathrm{h}$ [9] due to the low efficiency of porous surfaces in noise suppression for the velocity range up to $50-60 \mathrm{~km} / \mathrm{h}$ (according to various sources) Some authors, however, state that a noticeable noise reduction already occurs on the surface at 40 $\mathrm{km} / \mathrm{h}[10]$.

\section{Porous asphalt pavement maintenance}

In the maintenance of the surface of porous asphalt, the pores are cleaned with air, water and water with air. The first method consists of cleaning the pores with a stream of compressed air. It is considered less effective than water-based methods and frequent repetition is necessary. The method using water involves rinsing the surface with a stream of water under pressure. The third method consists in rinsing the surface with water and sucking the water together with impurities with an air suction nozzle. The contaminants are separated from the water and the water can be re-used for rinsing the surface. Rinsing devices with a pressure of about 200 bar are used (selected on the test section so that it is as effective as possible, but that it also does not cause damage to the porous layer). Traditional brushes (sweepers) should not be used because they squeeze the impurities into the pores and create a counter-productive effect, as well as mechanically damaging the porous layer. The first cleaning is recommended after about 3 months after the installation, and the 
cleaning should then be carried out at least twice a year (preferably in the autumn and after winter) $[11,12]$. In addition, the surface should be cleaned of chemical dirt, leaves and animal carrion. After the winter, the porous surface should be cleaned under pressure to remove all the impurities accumulated in the pores.

\section{Research of the contamination influence on porous asphalt pavement permeability}

Contamination of the surface from porous asphalt carries with itself the risk of effective drainage of rainwater inside its structure, and then outside - to drainage devices (Figure 1). Due to the contamination of the space between the aggregate grains, the volume of the chambers that quench the energy of acoustic pressure decreases or becomes filled with dust, sand and other impurities. Therefore, the noise suppression efficiency is reduced.

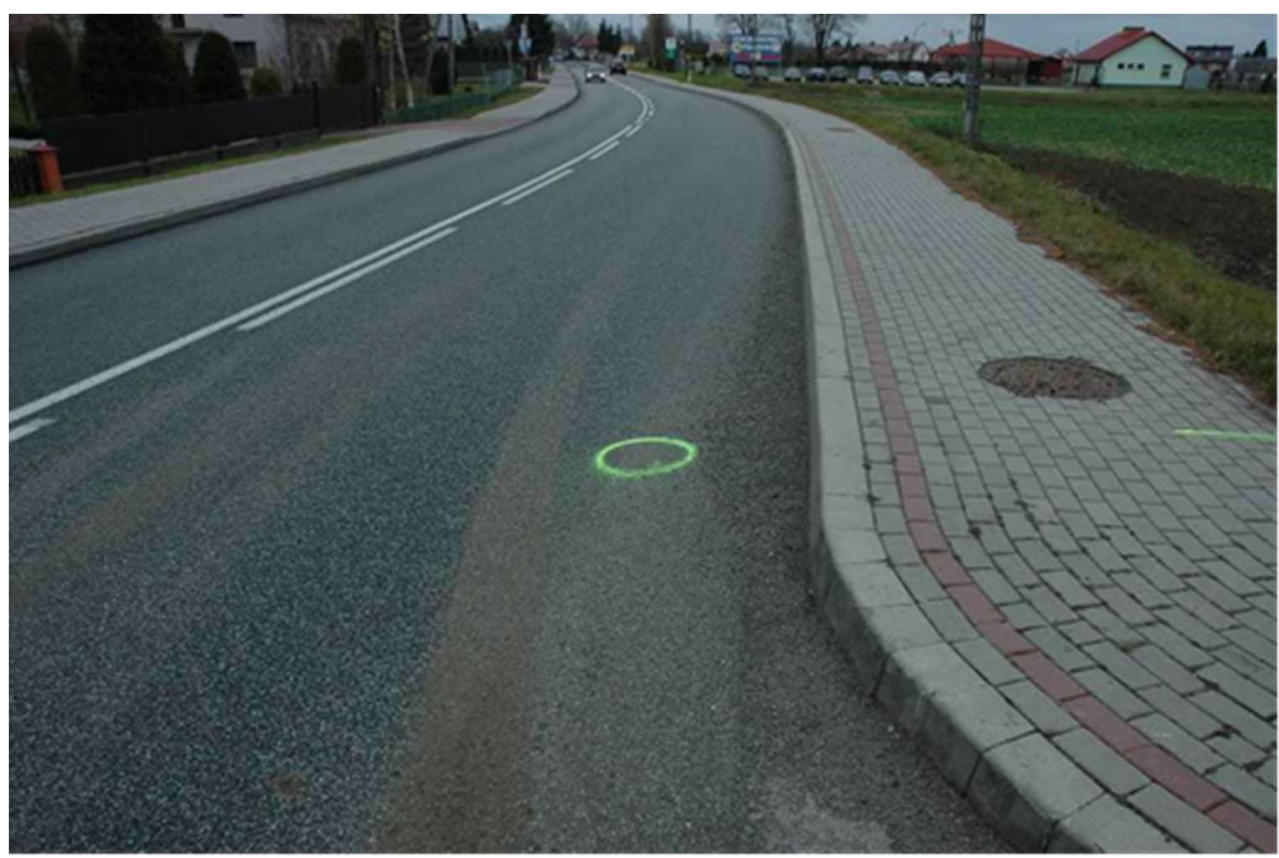

Fig. 1. An example of porous asphalt pavement pollution.

In order to estimate the degree of contamination of a surface made of porous asphalt, the samples taken from the pavement after a six-month period of use from the first cleaning were tested. The road on which the surface is made of porous asphalt is located in the Podkarpackie voivodeship, near the town of Leżajsk. The road runs through the built-up areas of an urban and rural character, on the length of which a pavement made of porous asphalt was made on the road. Core samples with a diameter of $100 \mathrm{~mm}$ were taken from the surface (Figure 2). 


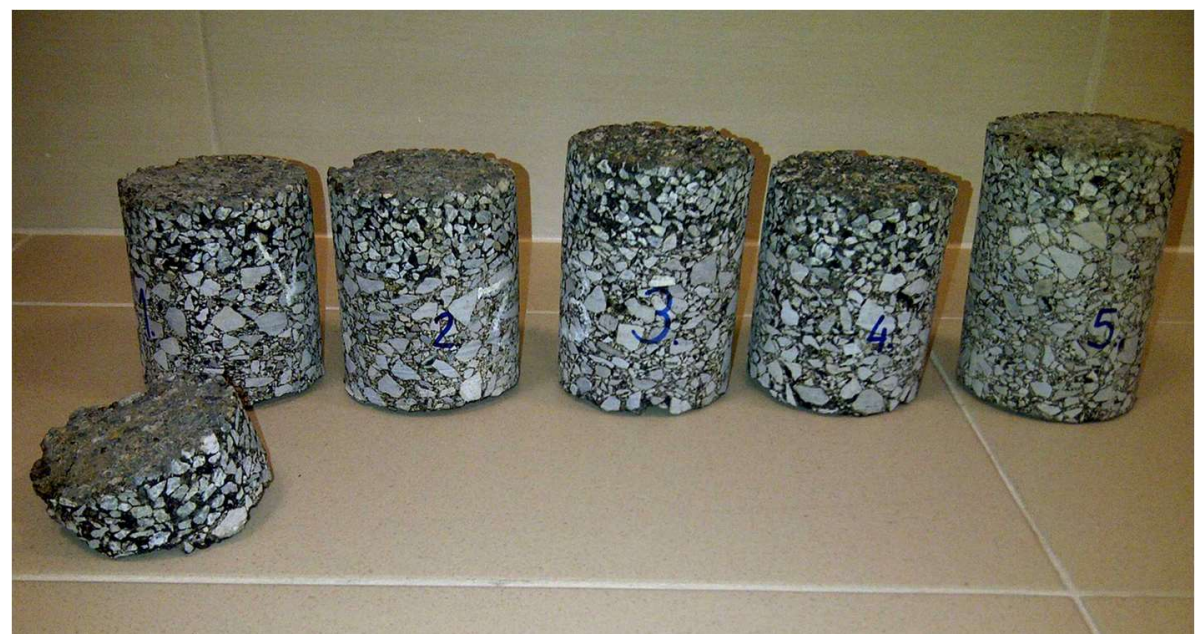

Fig. 2. The specimens from the investigated pavement.

An examination of the samples showed that the surface zone is heavily contaminated with fine material, and as the result of cleaning, the amount of binder bonding in the aggregate was reduced. Some of the collected samples were broken to visually determine the degree of filling of free spaces with contaminants. Strong contamination was found, virtually filling the open spaces (Figure 3).

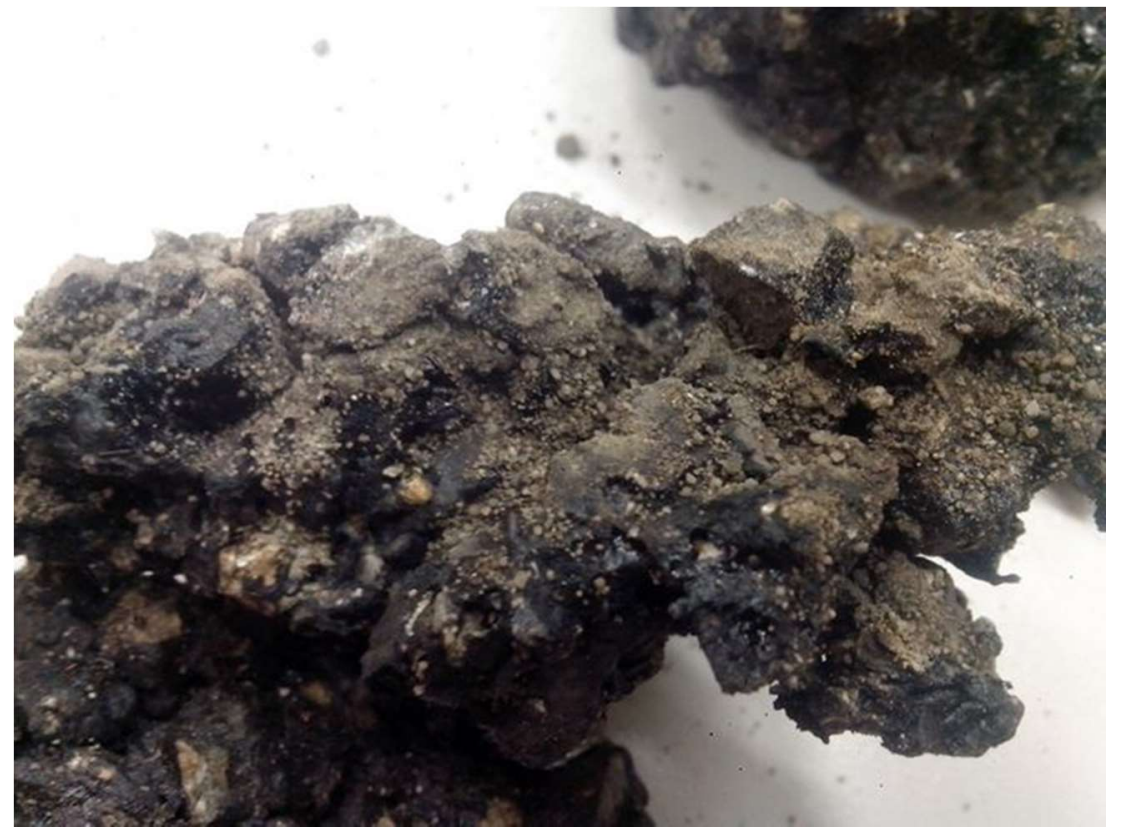

Fig. 3. The polluted specimen.

Laboratory tests were carried out in order to assess the water permeability of the porous asphalt. A water permeability test was performed in a specially constructed apparatus. It was made of a pipe section with a diameter adjusted to the diameter of the sample. The connection of the sample to the pipe was sealed with a rubber gasket. A constant water level was maintained in the pipe by a transfer located on the side of the tube. Everything was set on a steel mesh in such a way that all the water percolating through the sample 
could be collected. Before the actual test, the water was allowed to seep through the sample for at least 10 minutes to completely saturate the sample. After this time, the filtered water was collected in a bowl for 1 minute. For each sample, the amount of seeping water was determined 3 times. Water flow and water permeability were calculated based on the designs according to the technical regulations [13]. The formulas for the horizontal water permeability of samples were used for the calculations due to the fact that samples of porous asphalt were glued to the asphalt concrete layer with a membrane impermeable to water, making it impossible to flow vertically through the sample. In the experiment, the determined water column height above the sample was $0.31 \mathrm{~m}$. The test results are given in Table 1.

Horizontal flow through the sample:

$$
Q_{h}=\frac{m_{2}-m_{1}}{t} \times 10^{-6}
$$

where:

$Q_{h}$ - horizontal water flow through the sample $\left[\mathrm{m}^{3} / \mathrm{s}\right]$,

$m_{l}$ - weight of the empty container $[\mathrm{g}]$,

$m_{2}-$ weight of the container with water [g],

$t$ - time of collecting water [s],

Horizontal water permeability of the sample

$$
K_{h}=\frac{Q_{h} \times l}{(h+0,5 l) \times(\pi \times D \times l)}
$$

where:

$K_{h}$ - horizontal water permeability of the sample [m/s],

$Q_{h}$ - horizontal water flow through the sample $\left[\mathrm{m}^{3} / \mathrm{s}\right]$,

$l$ - thickness of the sample[m],

$h$ - height of the water column[m],

$D$ - diameter of the sample [m].

Table 1. Permeability of the porous asphalt specimen.

\begin{tabular}{|c|c|c|c|}
\hline $\begin{array}{c}\text { Specimen } \\
\text { number }\end{array}$ & Weight of the water $[\mathrm{g}]$ & $\begin{array}{c}\text { Water } \\
\text { flow } \\
{\left[\mathrm{m}^{3} / \mathrm{s}\right]}\end{array}$ & $\begin{array}{c}\text { Permeability } \\
{[\mathrm{m} / \mathrm{s}]}\end{array}$ \\
\hline \hline \multirow{3}{*}{3} & 743,0 & 0,0000124 & 0,000002 \\
\cline { 2 - 4 } & 773,8 & 0,0000129 & 0,000002 \\
\hline \multirow{3}{*}{4} & 767,9 & 0,0000128 & 0,000002 \\
\cline { 2 - 4 } & 402,0 & 0,0000067 & 0,000001 \\
\cline { 2 - 4 } & 399,3 & 0,0000067 & 0,000001 \\
\hline \multirow{3}{*}{6} & 393,3 & 0,0000066 & 0,000001 \\
\cline { 2 - 4 } & 1518,4 & 0,0000253 & 0,000003 \\
\cline { 2 - 4 } & 1491,0 & 0,0000249 & 0,000003 \\
\hline \multirow{3}{*}{7} & 1498,5 & 0,0000250 & 0,000003 \\
\cline { 2 - 4 } & 1567,2 & 0,0000261 & 0,000003 \\
\cline { 2 - 4 } & 1707,0 & 0,0000285 & 0,000004 \\
\hline
\end{tabular}




\section{Conclusions}

1. There was intense contamination in the surface layer of porous asphalt, to a depth of about $1-1.5 \mathrm{~cm}$ from the top of the sample.

2. The horizontal water permeability due to the contamination is small and significantly smaller than the results of laboratory tests reported in technical publications.

3. A visual inspection and testing of the wearing course made of porous asphalt:

a) showed very low water permeability due to heavy contamination of the pores in the upper surface layer thickness of $1-1.5 \mathrm{~cm}$,

b) showed strong action of water stream washing of the asphalt film from the top surface of the wearing course and between the parts of the aggregate grains to a depth of 1-2 mm,

b) did not show loss of wearing layer,

c) showed no damage in the freezing and thawing test.

\section{References}

1. Wytyczne techniczne WT-2, Instytut Badawczy Dróg i Mostów, Warszawa, (2010)

2. J. Olszacki, Przegląd doświadczeń projektowania i wykonywania nawierzchni porowatych, Nawierzchnie Asfaltowe, 4 (2006)

3. D. Sybilski, W. Bańkowski, A. Wróbel, Ciche nawierzchnie asfaltowe z zastosowaniem granulatu gumowo-asfaltowego, Ochrona środowiska $i$ estetyka a rozwój infrastruktury drogowej, SITK, 291-300 (2011)

4. R. Gołębiewski, Zmiana skuteczności akustycznej cichych nawierzchni drogowych z upływem czasu, http://www.umweltaktion.de, (2018.02.26)

5. J. Judycki, P. Jaskuła, Nowoczesne nawierzchnie asfaltowe, XLVII Techniczne Dni Drogowe, 75-94 (2004)

6. J. Olszacki, Określenie wodoprzepuszczalności i dźwiękochłonności betonów asfaltowych stosowanych w nawierzchniach drenujących, doctoral thesis, Politechnika Świętokrzyska (2005)

7. R. Gołębiewski, Zmiana skuteczności akustycznej cichych nawierzchni drogowych z upływem czasu, http://www.umweltaktion.de, (2018.02.26)

8. Bulletin of Orlen - Asphalt, 3, Orlen (2006)

9. J. Piłat, P. Radziszewski, Nawierzchnie asfaltowe, WKi屯, 369 (2010)

10. J. Olszacki, Przegląd doświadczeń projektowania i wykonywania nawierzchni porowatych, Nawierzchnie Asfaltowe, 4, 2-10 (2006)

11. R. McDaniel, W. Thornton, J.G. Dominiguez, Field evaluation of porous asphalt pavement, Final Report SQDH 2004-6, Purdue University (2004)

12. I. Ruttmar, T. Oracz, A. Dudek, J. Król, Eksploatacja i utrzymanie nawierzchni z asfaltu porowatego, Zastosowanie Nowoczesnych Technologii w Konstrukcjach Drogowych, $\quad$ http://edroga.pl/images/stories/nwb technologie/polski-test-asfaltuporowatego/tpa ruttmar.pdf (2018.02.26)

13. PN-EN 12697-19 Asphalt mixtures. Methods of testing hot-mix asphalt mixtures. Part 19: Water permeability of samples. 